\title{
Relationship between Mandibular Nerve Block Anesthesia and Body Mass Index in Children
}

\author{
Relación entre la Anestesia del Nervio Mandibular \\ y el Índice de Masa Corporal en Niños
}

\author{
Viviana Castillo*; Andrea Cerón ${ }^{*}$ Ricardo Cartes-Velásquez ${ }^{* *}$ Pedro Aravena $^{*, * *}$
}

CASTILLO, V.; CERÓN, A.; CARTES-VELÁQUEZ, R. \& ARAVENA, P. Relationship between mandibular nerve block anesthesia and body mass index in children. Int. J. Odontostomat., 6(1):71-75, 2012.

\begin{abstract}
The aim of this study was to observe the relationship between the anesthetic block sucess (ABS) of mandibular nerve, by injecting $1.8 \mathrm{ml}$ of lidocaine $2 \%$ with epinephrine 1:100,000, in children and their body mass index (BMI). A prospective cohort study was designed. A sample of 93 6-13 years children attended in JUNAEB Dental Module of Frutillar between April and July 2011. We recorded age, gender, reason for tooth extraction and tooth type (permanent or deciduous). BMI was calculated for each child and categorized into two cohorts of study according to WHO criteria: those with a BMI <p85 were defined as "low - normal weight" (LNW) and those with a BMI equal or >p85 as "over weight - obese" (OWO). After applying the anesthetic technique, effect was evaluated at 10 minutes recording its effectivenes. We analyzed statistically significant relationship between ABS and BMI using Fisher's exact test with $(p<0.05)$. Anesthetic effect was achieved in 84 children (90.3\%) with a $89.36 \%$ in LNW group and $91.30 \%$ in OWO group. There was no statistically significant relationship between $\mathrm{ABS}$ and $\mathrm{BMI}(\mathrm{p}=1.0)$. There is no relationship between anesthetic effectiveness of mandibular nerve and body mass index in children.
\end{abstract}

KEY WORDS: local anesthesia, body mass index, children, mandibular nerve.

\section{INTRODUCTION}

Anesthetic block of mandibular nerve and its branches (ABMN) in children is used for rehabilitation treatment, endodontics and dental extractions (Escobar, 2004). It have a failure rate between $15 \%$ and $20 \%$ (Malamed, 2006), that may be due to the anesthetic solution, expiration or more frequently by a technical (anatomic) error; may be a failure due to biological reasons, such as local inflammation that determine a low $\mathrm{pH}$ (Escobar) or anatomic variations such as accessory sensory innervation of mandibular teeth by the accesory cervical and mylohyoid nerves (Malamed). On the other hand, we must consider the pharmacokinetics of drugs, given that there are factors that may affect its distribution, like: binding to plasma proteins, body composition and regional blood flow (Passannante \& Rock, 2005).

Although it has not been studied at length, the plasma protein binding does not appear to be significantly different in obese individuals given that blood volume increases directly with body weight and that many patients have an increased cardiac output. This point has implications regarding anesthetic, both injected and inhaled. Still, the obesity pandemic has not led to an increase in pharmacokinetic studies in obese patients (Passannante \& Rock).

Currently there are no published studies who report the association between obesity, measured through Body Mass Index (BMI), and local anesthesia, considering BMI as the best anthropometric indicator for diagnose overweight and obesity in children between 2 and 18 years old (Burrow et al., 2004). In addition, the variability of success rates for ABMN reported between $10 \%$ to $39 \%$ (Fernandez et al., 2005) highlights the importance to observe whether the different levels of BMI in children could affect the effectiveness of local anesthesia in dental procedures.

\footnotetext{
* Institute of Odontostomatology. Faculty of Medicine. Universidad Austral de Chile, Chile.

* PhD Program in Medical Sciences. Faculty of Medicine. Universidad de la Frontera, Chile.
} 
The aim of this study is to observe the relationship between the anesthetic block sucess (ABS) of mandibular nerve, by injecting $1.8 \mathrm{ml}$ of lidocaine $2 \%$ with epinephrine 1:100,000, in children and their BMI.

\section{MATERIAL AND METHOD}

A prospective cohort study was designed. We performed a simple random sampling of children whose attended in JUNAEB Dental Module of Frutillar, between April and July 2011. Selection criteria were: children between 6 and 13 years, indicating the extraction of premolar or molars (permanent or deciduous), health status ASA I and II. We excluded all patients with: acute dentoalveolar abscess, difficult management, psychological disorders or who were consuming drugs that altered pain perception.

Ethical considerations, in selected patients parents, as the legal representatives, were asked to participate in this research with the approval of informed consent form provided by the Department of Health of Frutillar. Likewise, the child was asked at the time of attention for his/her consent to participate in the study.

Examination and clinical history was performed, recording: name, sex, age and diagnosis of tooth to be extracted. BMI was calculated based on Quetelet (BMI $=$ weight $/$ height $^{2}$ ) and its percentile values for classifying nutritional situation among children and adolescents based on WHO criteria (MINSAL, 2004) whose distribution is: underweight $<\mathrm{p} 10$, normal between p10 and <p85, p85 up to p94 for overweight and obese for greater than or equal to p95 (Loaiza et al., 2009). Each child was measured and weighed with a DETECTO $\otimes$ (Colombia) stadiometer with balance. This procedure was performed by two investigators (AC and $\mathrm{VC}$ ), previously calibrated by a Nutritionist of Frutillar Health Service. After determining the BMI of each patient, they were classified into two weight cohorts according to WHO criteria:

- Low - normal weight (LNW): is a group of children classified with a BMI which was percentile <p85.

- Over weight - obese (OWO): is a group of children classified with a BMI percentile over or equal to p85.

Anesthetic Technique: An investigator (VC) proceeded to $A B M N$ as described by Malamed. For this purpose, dried mucosa with a cotton ball in the retromolar trigone, then applied a benzocaine $20 \%$ topical anesthetic gel
(Mayon $\AA$, Chile) and waited for a minute. Anesthesia cartridge was heated up to body temperature over a burner and then proceeded to anesthesia of MN and its branches: the inferior alveolar nerve, lingual nerve and buccal nerve, using a $27 \mathrm{G}$ syringe needle carpule $0.4 \mathrm{~mm} \times 25 \mathrm{~mm}$ (Terumo Corporation, Japan), by injecting $1.8 \mathrm{ml}$ (1 tube) of lidocaine $2 \%$ with epinephrine 1:100.000 (Ortocaine 100 ®). As described by Escobar the puncture site is a depression mucosa, at that point, formed by the medial pterygoid muscle, going from the opposite side (distal cusp of the 2 nd molar) at a depth of 8 or $10 \mathrm{~mm}$ from the surface, it reaches the vicinity of the foramen, which is surrounded by foraminas. This facilitates the diffusion of the solution. Thus, after the puncture aspiration was performed to verify that we are not inside a blood vessel.

Lingual nerve was anesthetized at middle distance of the withdrawal of the needle and buccal one through anesthesia infiltration in the anterior border of the ramus and laterally to retromolar trigone.

After 10 minutes, ABMN was checked by sindesmotomy, if patient reported pain or discomfort, we waited an additional 5 minutes. ABS was defined as the possibility to perform the extraction of the tooth with no pain or minimal pain tolerated by the patient. Otherwise, it was considered ineffective, strengthening the technique by injecting $0.9 \mathrm{ml}$ to $\mathrm{MN}$ or infiltrating at buccal side of tooth.

In statistical analysis, to calculate sample size, we considered a target population of 2806 to 13 years children attended during the months of the study, $90 \%$ of anesthetic sucess (Fernandez et al.), a margin of error of $5 \%$ and statistical significance of $5 \%$, obtaining a estimation of 93 children.

Descriptive statistics was applied, chi square and t-test was used to determine significant differences between LNW and OWO groups for control variables (age, sex and tooth type). We analyzed statistically significant relationship between $A B S$ and BMI using Fisher's exact test. All statistical calculations were analyzed with a significance level of $p<0.05$ using STATA 10.0 (StataCorp, USA).

\section{RESULTS}

There were 313 patients, of which 145 met the selection criteria. Finally, 93 children agreed to 
participate in the study with a mean age of 9.03 years $(S D=1.72$ $\min =6 \max =13)$. Of these, 49 were men $(52.7 \%)$ and $50.53 \%$ belong to LNW group. There were no statistical differences in gender $(p=0.35)$, age $(p=0.30)$ and type of teeth extracted ( $p$ $=0.14$ ) between the two groups (Table I).

Table I. Clinical and demographic characterization of patients by weight groups.

\begin{tabular}{lcccc}
\hline & & \multicolumn{3}{c}{ Weight group } \\
\cline { 3 - 5 } & & LNW & OWO & p value \\
\hline Sex & Male & 27 & 22 & $0.35^{*}$ \\
\multirow{4}{*}{ Age } & Female & 20 & 24 & \\
Tooth type & Mean (SD) & $9.21(1.84)$ & $8.84(1.59)$ & $0.30^{* *}$ \\
& Deciduous & 38 & 42 & $0.14^{*}$ \\
& Permanent & 9 & 4 & \\
& Permy
\end{tabular}

${ }^{*}$ chi square and ${ }^{* *}$ t-test

Most of extractions corresponded to deciduous teeth $(93.75 \%)$. Main reason for extraction were for orthodontic indications $(n=44)$, followed by decay $(n=33)$ and the rest due to physiological mobility near to exfoliation $(n=16)$.

Anesthetic effect was achieved in 84 children (90.3\%) with a $89.36 \%$ in LNW group and $91.30 \%$ in OWO group. There was no statistically significant relationship between ABS and BMI $(p=1.0)$. The details of these results are shown in Table II.

Table II. ABS by weight group.

\begin{tabular}{lccc}
\hline & \multicolumn{3}{c}{ ABS } \\
Weight group & Yes & No & p-value \\
\hline LNW & 42 & 5 & \\
OWO & 42 & 4 & \\
Total (\%) & $84(90.32)$ & $9(9.68)$ & $1.00^{*}$ \\
\hline
\end{tabular}

${ }^{*}$ Fisher's exact test

\section{DISCUSSION}

In this study we observed a high rate of $A B S$ for $M N$ in pediatric patients treated for both primary and permanent teeth extractions. However, there was no statistically significant relation with BMI.

Our study reported a $9.7 \%$ anesthetic failure, a result similar to the ranges published by Goodman et al. (2006). Haase et al. (2008) reported that buccal nerve infiltration can reduce the failure rate and the onset of pulpal anesthesia after ABMN. Furthermore, the same author reports that $4 \%$ articaine with
$1: 100,000$ epinephrine is superior to lidocaine $2 \%$ with epinephrine $1: 100,000$ in buccal infiltration in the mandibular first molar.

Using a single cartridge of $1.8 \mathrm{ml}$ for $A B M N$ is sufficient to achieve $A B S$, this has been proved by Foster et al. (2007) who shows that there were no significant differences in ABS with either $1.8 \mathrm{ml}$ or $3.6 \mathrm{ml}$ volume of lidocaine. In addition, it minimizes potential complications and adverse reactions because children are more likely to develop toxic reactions than adults due to their lower anatomical proportions (Wright et al., 1989).

ABS seems be related to dentist-factors (initial dose administered, surgical procedure, oral premedication) and children characteristics and behavior, like: age, gender, arch treated, anxiety level and the presence of symptoms before injection (Nakai et al., 2000).

Also, the pain is associated with anxiety what can distort the level of consciousness causing an increase in awareness of surroundings objects or situations, nonspecific reactivity to pain and vegetative reactions (Amez-Atapoma \& Díaz-Pizán, 2010). When there is no pain and anesthetic effect is achieved, the child feels comfortable, this being good for child and dentist (Welbury, 2005).

Theories of $A B M N$ failure include crossinnervation, accessory innervation, precision placement of the needle, anesthetic solution migration through tissues of least resistance, core theory, anxiety and psychological factors (Clark et al., 2002). This is the reason because anxious and difficult to manage patients were excluded from this study. However, there are other possible biases in this study.

Moreover, the position of the mandibular foramen varies with age of child, at 4 years or less, the hole is located below the plane of occlusion. In a young child, hole is in the occlusal plane. As the child matures, it moves to a higher position (Ram \& Peretz, 2002), factor that can cause a ABMN failure if anatomic development is not considered.

In relation to the weight of patients, there was no statistical association with the 
anesthetic effect. Although the accuracy of BMI to estimate body composition is debatable, being affected by sex, race and age, which may lead to misclassification of obesity status (Baumgartner et al., 1995).

We must highlight that there are no published studies about relation between effectiveness of local anesthesia in dentistry with the patient's weight. There are only reports that compare different types of anesthesia, volumes and concentrations, the majority focused on adult population.

Therefore, it is recommended to perform (descriptive or analytical) observational studies and randomized controlled trials, assessing effectiveness of different local anesthetics and their relation with fat percentage, measured by skinfold thickness. As well, to evaluate pharmacokinetics of local anesthetics used in dentistry, because it is not certain whether individual anthropometric factors can influence on ABS in both pediatric and adult patients.

\section{ACKNOWLEDGMENTS}

We thank Dr. Sandra Alvarez, Director of JUNAEB Dental Module at Frutillar, Ms. Pamela Gopaldas, Frutillar Health Department Director and to Dr. Sergio Krause, Director of Institute of Pediatrics, Universidad Austral de Chile for the facilities and support in this research. This paper is based on a thesis submitted in partial fulfillment of the requirements for the degree of Bachelor in Dental Surgery in the School of Dentistry of the Universidad Austral de Chile, 2011.

CASTILLO, V.; CERÓN, A.; CARTES-VELÁQUEZ, R. \& ARAVENA, P. Relación entre la anestesia del nervio mandibular y el índice de masa corporal en niños. Int. J. Odontostomat., 6(1):71-75, 2012.

RESUMEN: El objetivo de este trabajo fue observar la relación entre el bloqueo anestésico efectivo (BAE) del nervio mandibular, inyectando 1,8 ml de lidocaína al 2\% con epinefrina 1:100.000, en niños y su índice de masa corporal (IMC). Fue diseñado un estudio de cohorte prospectivo. Se seleccionó una muestra de 93 niños que se atienden en el Módulo Dental de JUNAEB de Frutillar entre abril y julio de 2011. Se registró edad, sexo, motivo de la exodoncia y tipo de diente (permanente o deciduo). Se calculó el IMC para cada niño, que fue categorizado en 2 cohortes de acuerdo al criterio de la OMS: "bajo peso - normal" (BPN) para aquellos con un IMC <p85 y "sobre peso - obeso" (SPO) para con IMC igual o >p85. Después de aplicar la técnica anestésica, a los 10 minutos se evaluó su efectividad registrando el BAE. Se analizó la relación estadística entre IMC y BAE mediante Test exacto de Fisher $(p<0,05)$. Se logró el BAE en 84 niños $(90,3 \%)$, con un $89,36 \%$ en el grupo BPN y $91,30 \%$ en el grupo SPO. No se halló una asociación estadísticamente significativa entre BAE e IMC $(p=1,00)$. No existe relación entre la efectividad del bloqueo anestésico del nervio mandibular y el índice de masa corporal en niños.

PALABRAS CLAVE: anestésico local, índice de masa corporal, niños, nervio mandibular.

\section{REFERENCES}

Amez-Atapoma, J. \& Díaz-Pizán, M. E. Manejo del dolor en odontopediatría. Rev. Estomatol. Herediana, 20(3):166$71,2010$.

Baumgartner, R. N.; Heymsfield, S. B. \& Roche, A. F. Human body composition and the epidemiology of chronic disease. Obes. Res., 3(1):73-95, 1995.

Burrows, R. A.; Díaz, N. \& Muzzo, S. Variations of body mass index (BMI) according to degree of pubertal development. Rev. Med. Chil., 132(11):1363-8, 2004.

Clark, K.; Reader, A.; Beck, M. \& Meyers, W. Anesthetic efficacy of an infiltration in mandibular anterior teeth following an inferior alveolar nerve block. Anesth. Prog., 49(2):49-55, 2002.
Escobar, M. F. Odontología Pediátrica. Capitulo VII. $2^{\mathrm{a}}$ ed. Caracas, Amolca, 2004. pp.171-80.

Fernandez, C.; Reader, A.; Beck, M. \& Nusstein, J. A prospective, randomized, double-blind comparison of bupivacaine and lidocaine for inferior alveolar nerve blocks. J. Endod., 31(7):499-503, 2005.

Foster, W.; Drum, M.; Reader, A. \& Beck, M. Anesthetic efficacy of buccal and lingual infiltrations of lidocaine following an inferior alveolar nerve block in mandibular posterior teeth. Anesth. Prog., 54(4):163-19, 2007.

Goodman, A.; Reader, A.; Nusstein, J.; Beck, M. \& Weaver, $J$. Anesthetic efficacy of lidocaine/meperidine for inferior alveolar nerve blocks. Anesth. Prog.,. 53(4):131-9, 2006. 
Haase, A.; Reader, A.; Nusstein, J.; Beck, M. \& Drum, M. Comparing anesthetic efficacy of articaine versus lidocaine as a supplemental buccal infiltration of the mandibular first molar after an inferior alveolar nerve block. J. Am. Dent. Assoc., 139(9):1228-35, 2008.

Loaiza, M. S.; Taibo, G. M.; Cornejo, A. \& Atalah, S. E. Evolution of nutritional status in a cohort of school age children. Rev. Med. Chil., 137(11):1449-56, 2009.

Malamed, S. F. Manual de anestesia local. Capítulo 14. $5^{a}$ ed. Madrid, Elsevier, 2006. pp.227-35.

MINSAL. Unidad de Nutrición del Ministerio de Salud. Consejo Asesor en Nutrición. Norma técnica de evaluación nutricional del niño de 6 a 18 años. Año 2003. Rev. Chil. Nutr., 31(2):128-37, 2004.

Nakai, Y.; Milgrom, P.; Mancl, L.; Coldwell, S. E.; Domoto, P. K. \& Ramsay, D. S. Effectiveness of local anesthesia in pediatric dental practice. J. Am. Dent. Assoc., 131(12):1699-705, 2000.

Passannante, A. N. \& Rock, P. Anesthetic management of patients with obesity and sleep apnea. Anesthesiol. Clin. North Am., 23(3):479-91, 2005.

Ram, D. \& Peretz, B. Administering local anaesthesia to paediatric dental patients - current status and prospects for the future. Int. J. Paediatr. Dent., 12(2):80-9, 2002.

Welbury, R. R.; Duggal, M. S. \& Hosey, M. T. Paediatric dentistry. 3rd ed. Oxford, Oxford University Press, 2005.

Wright, G. Z.; Weinberger, S. J.; Friedman, C. S. \& Plotzke, O. B. Use of articaine local anesthesia in children under 4 years of age--a retrospective report. Anesth. Prog., 36(6):268-71, 1989.
Correspondence to:

Pedro Aravena

Institute of Odontostomatology, Faculty of Medicine

Universidad Austral de Chile

Rudloff 1640, Valdivia

CHILE

Phone: (56-63) 293751

Email: paravena@uach.cl

Received: 02-11-2011

Accepted:18-01-2012 